\title{
Altitudinal distribution of lotic chironomid (Diptera) communities in the Sierra Nevada mountains (Southern Spain)
}

\author{
J.J. Casas 1
}

A. Vilchez-Quero ${ }^{1}$

Keywords : Diptera, Chironomidae, altitudinal distribution, streams, Sierra Nevada, Spain.

Pupae and pupal exuviae were collected by drift and hand netting from 27 sites on 10 streams in the Sierra Nevada mountains in 1986 and 1987. The sites represented an altitudinal range from $340 \mathrm{~m}$ to $2100 \mathrm{~m}$. The pupal exuviae collections revealed a composite fauna of 143 species. Eukiefferiella $(12 \mathrm{spp}$.) and Tvetenia $(3 \mathrm{spp}$.) were dominant both taxonomically and numerically along most of the altitudinal profile, followed by Cricotopus (11 spp.), Orthocladius ( $9 \mathrm{spp}$.) and Diamesa (7 spp.).

The altitudinal distribution of the 99 most common species is shown and compared with those obtained in other European streams or rivers, especially in the Pyrenees. The general pattern of altitudinal zonation shows an increase in species richness from the headwaters $(<2000 \mathrm{~m}: 58 \mathrm{spp}$.) toward the middle reaches $(1000-1600 \mathrm{~m}: 121 \mathrm{spp}$.). The theoretically expected highest species richness in the foothill reaches $(>1000 \mathrm{~m}: 113 \mathrm{spp}$.) was not obtained. The periods of reduced or intermittent flow, the domestic organic inputs and the narrowness of the channels in the foothill reaches appear responsible for the decrease of the species richness of the chironomid communities.

Répartition altitudinale des communautés lotiques de Chironomidés (Diptera) de la Sierra Nevada (Sud de l'Espagne)

Mots clés : Diptera, Chironomidés, répartition altitudinale, rivières, Sierra Nevada, Espagne.

Des exuvies nymphales et des nymphes de Chironomidés ont été récoltées par dérive ou dans des zones d'accumulation, dans 27 stations de 10 rivières de la Sierra Nevada, en 1986 et 1987. Les stations sont échelonnées entre $340 \mathrm{~m}$ et $2100 \mathrm{~m}$ d'altitude. 143 espèces ont été identifiées. Les Eukiefferiella $(12 \mathrm{spp}$.) et les Tvetenia $(3 \mathrm{spp}$.) sont les deux genres dominants, spécifiquement et numériquement, tout au long de la zone altitudinale prospectée, suivis par les $C r i-$ cotopus (11 spp.), les Orthocladius (9 spp.) et les Diamesa ( $7 \mathrm{spp}$.$) .$

La répartition altitudinale des 99 espèces les plus fréquentes est comparée avec celle d'autres rivières d'Europe, et plus spécialement des Pyrénées. Le modèle général de zonation altitudinale présente une augmentation de la richesse spécifique depuis les sources ( $>2000 \mathrm{~m}: 58 \mathrm{spp}$.) jusqu'aux zones de moyenne altitude $(1000-1600 \mathrm{~m}: 121 \mathrm{spp}$.). La théoriquement attendue plus forte diversité spécifique dans les zones de piémont (>1000 m:113 spp.) ne s'est pas vérifiée. Les périodes de réduction ou d'intermittence des débits, la pollution organique et l'étroitesse du lit des rivières du piémont semblent les causes de cette diminution de la richesse spécifique des communautés de Chironomidés.

\section{Introduction}

The gradient of environmental conditions that occurs as a function of altitude offers excellent opportunities to investigate factors which influence the diversity, composition and abundance of stream organisms (Ward 1986). Factors such as thermal regime, flow and characteristics of the substratum, which have primary importance in the distribution of most lotic chironomid species, are directly or indi-

1. Departamento de Biologia Animal y Ecologia, Facultad de Ziencias, Universidad de Granada, 18071, Granada, Spain. rectly dependent on altitude. Altitudinal gradient is considered by Coffman (1989) as one of the major factors that influences the richness of a lotic chironomid community.

Altitudinal zonation patterns of lotic chironomids have been studied in Europe since Thienemann (1954) proposed a classification system for European rivers based on their chironomid fauna. However, some of the studies are limited in taxonomic scope, or present difficulties in the interpretation of the natural longitudinal or altitudinal distribution patterns due to disturbances (review in Laville \& 
Vinçon 1991). Preliminary information on the altitudinal distribution of chironomids in the streams of the Sierra Nevada is available in Casas \& Vilchez (1989). The aim of the present work is to offer some general data on the composition of the lotic chironomid communities in this massif. Furthermore, we shall examine the altitudinal distribution pattern of the most frequent species, comparing our data with other European mountains, and discussing the influence of some special features of the study area on the altitudinal pattern of species richness. In the context of the present paper the term " community " follows the definition of " species assemblage » as stated by Giller (1984).

\section{Study area}

The study was carried out in 10 streams in the western part of the Sierra Nevada, Andalucía (Southern Spain). This is the most Southern European highmountain massif, representing heights up to $3300 \mathrm{~m}$ (Fig. 1). The streams studied form the headwaters

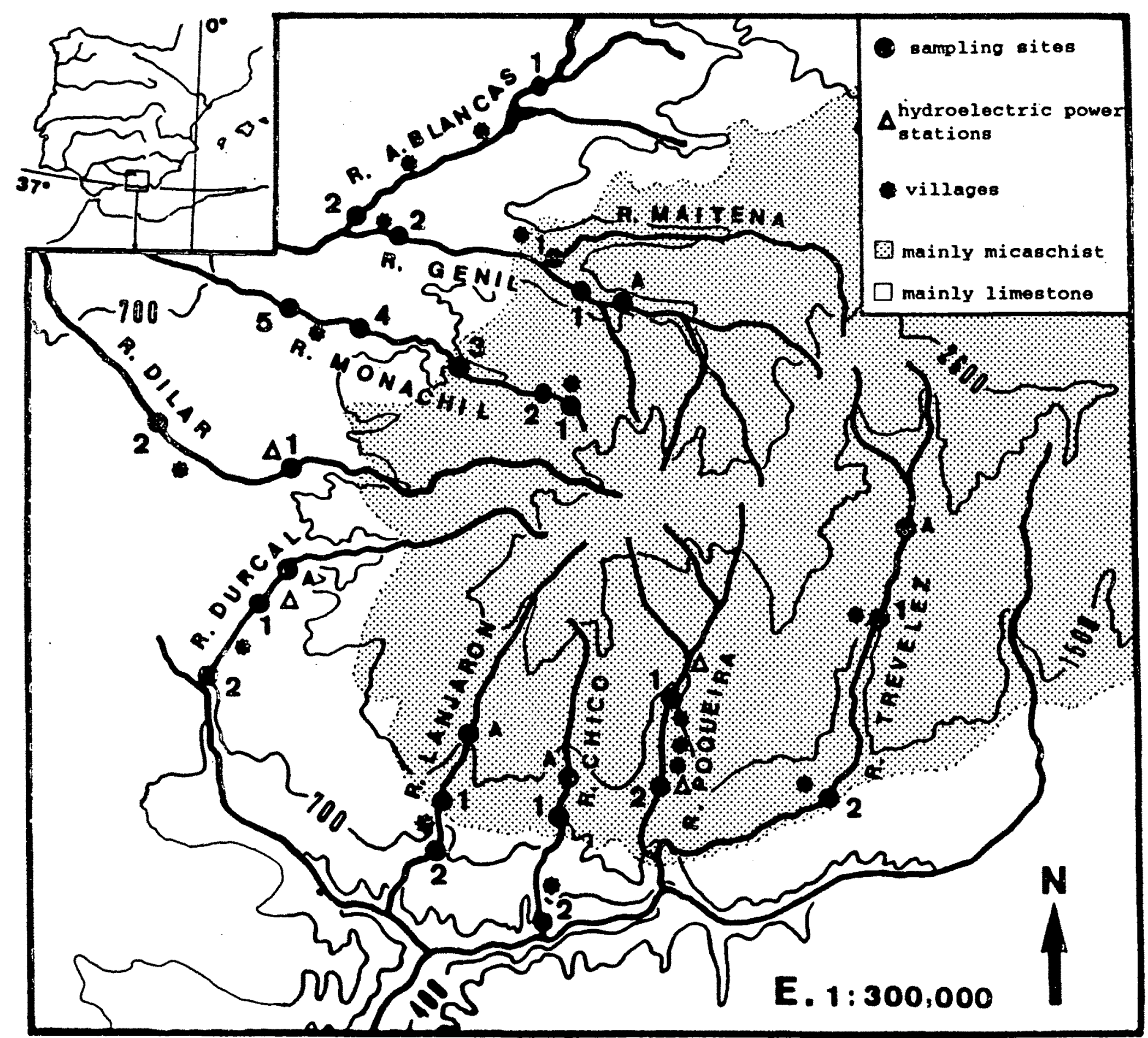

Fig. 1. Map of the Western part of the Sierra Nevada, showing the sampling sites on the streams studies.

Fig. 1. Carte de la Sierra Nevada occidentale : localisation des 27 stations dans les 10 rivières étudiées. 
of the rivers Guadalfeao, on the southern face, andGenil on the northern face. The streams have torrential flow, primarily in spring during the snow melt, but reduced flow in summer (Table 1). Twenty-seven sampling sites were studied (Fig. 1), ranging from 340 to $2100 \mathrm{~m}$ a.s.l. . The substratum was chiefly composed of boulders, angular rubble and gravel. In the upper reaches there is a great development of the algae Hydrurus foetidus during winter and spring. In the lower reaches some domestic effluents enter the streams. Impoundment of water to provide for small hydroelectric power stations and irrigation takes place mainly below $1000 \mathrm{~m}$. More detailed information concerning the physiographic and chemical characteristics of the sampling stations is provided in Table 1.

\section{Material and methods}

The material, pupal exuviae and pupae of Chironomidae, was collected by drift netting $\left(875 \mathrm{~cm}^{2}\right.$ mouth, $1.1 \mathrm{~m}$ long. $250 \mu \mathrm{m}$ mesh size). The nets, 1 or 2 depending on stream width, were placed in the centre of the channel. Collections were made for an hour and a half at every sampling site during four periods : May-June 1986, August 1986, November 1986, March 1987. Generally, for each stream the

Table 1. Physiographical and chemical characteristics of the sampling stations : mean values ; maximum and minimum values for flow and water temperature.

Tableau 1. Caractéristiques physico-chimiques des stations étudiées : valeurs moyennes ; valeurs maximum et minimum pour le débit et la température de l'eau.

\begin{tabular}{|c|c|c|c|c|c|c|c|c|c|c|c|c|}
\hline 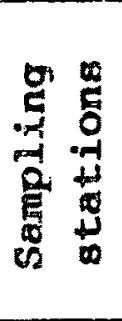 & 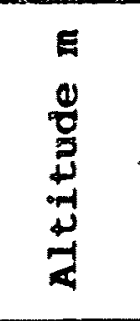 & 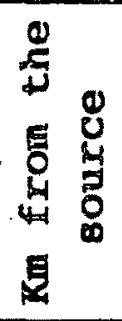 & 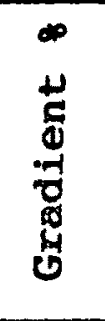 & 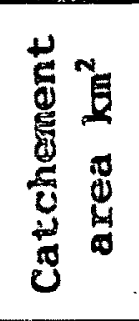 & 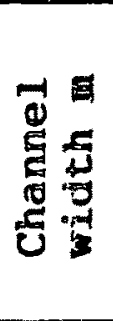 & 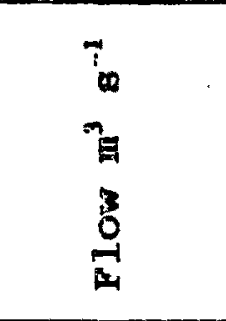 & $\begin{array}{l}0 \\
0 \\
5\end{array}$ & 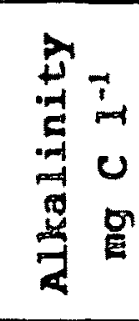 & 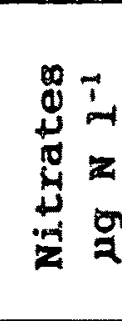 & 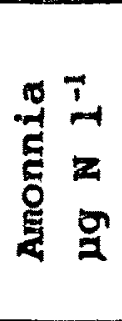 & 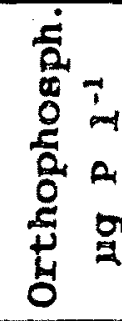 & 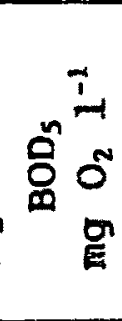 \\
\hline TA & 1700 & 8.5 & 16.9 & 43.1 & 4.4 & 0.59 & 16 & 12.2 & 46 & 45 & 0 & $=$ \\
\hline TI & 1460 & 13.0 & 3.5 & 75.5 & 7.1 & $0.20-3.09$ & $11-19$ & 16.9 & 116 & 25 & 14 & 1.06 \\
\hline$T 2$ & 1000 & 21.5 & 4.4 & 115.1 & 4.0 & $0.37-2.23$ & $9-19$ & 22.3 & 139 & 45 & 13 & 1.59 \\
\hline PI & 1300 & 9.2 & 9.5 & 60.5 & 4.5 & $0.04-0.30$ & $9-17$ & 44.7 & 174 & 50 & 1 & 0.98 \\
\hline P2 & 960 & 12.5 & 10.0 & 78.9 & 4.0 & $0.17-1.23$ & $12-19$ & 61.3 & 280 & 68 & 52 & 1.21 \\
\hline $\operatorname{Ch} A$ & 900 & 8.7 & 32.0 & 22.1 & 2.2 & 0.02 & 16 & 109.8 & 1.46 & 32 & 0 & - \\
\hline $\mathrm{Ch} 1$ & 740 & 9.5 & 22.5 & 25.9 & 2.3 & $0.00-0.59$ & $9-14$ & 82.0 & 124 & 59 & 1 & 0.86 \\
\hline $\operatorname{ch} 2$ & 340 & 15.0 & 5.0 & 32.6 & 1.6 & $0.00-0.20$ & $19-27$ & 152.5 & 775 & 83 & 7 & 1.09 \\
\hline LA & 1500 & 10.5 & 13.0 & 18.4 & 2.9 & 0.08 & 14 & 18.9 & 313 & 34 & 0 & - \\
\hline LI & 720 & 14.7 & 18.3 & 26.4 & 2.4 & $0.01-0.55$ & $10-16$ & 94.1 & 162 & 39 & 3 & 1.25 \\
\hline 12 & 600 & 16.2 & 15.2 & 27.9 & 2.5 & $0.00-0.69$ & $13-20$ & 184.0 & 295 & 277 & 165 & 7.72 \\
\hline$D A$ & 860 & 13.5 & 8.0 & 45.1 & 2.5 & 0.02 & 19 & 139.1 & 37 & 23 & 0 & - \\
\hline DI & 780 & 15.3 & 5.5 & 52.7 & 2.8 & $0.04-0.99$ & $8-18$ & 117.1 & 437 & 41 & 2 & 1.80 \\
\hline D2 & 680 & 19.7 & 3.0 & 68.4 & 4.1 & $0.18-1.32$ & $11-18$ & 186.5 & 2047 & 744 & 527 & 6.63 \\
\hline Dil & 980 & 17.0 & 5.0 & 43.1 & 2.6 & $0.02-0.82$ & $9-19$ & 140.7 & 186 & 37 & 0 & 0.78 \\
\hline Di2 & 800 & 24.0 & 2.5 & 66.6 & 3.0 & $0.03-0.66$ & $10-16$ & 132.9 & 1000 & 40 & 0 & 2.03 \\
\hline$M 1$ & 2100 & 2.5 & 20.4 & 5.5 & 2.4 & $0.03-0.44$ & $4-11$ & 21.3 & 268 & 18 & 6 & 0.45 \\
\hline M2 & 1960 & 3.0 & 60.2 & 6.4 & 1.9 & $0.10-0.45$ & $4-11$ & 25.9 & 450 & 25 & 12 & 0.99 \\
\hline$M 3$ & 1400 & 7.5 & 11.6 & 27.2 & 4.3 & $0.26-1.96$ & $7-18$ & 58.1 & 342 & 56 & 36 & 1.78 \\
\hline M4 & 940 & 14.5 & 6.9 & 51.1 & 3.3 & $0.06-1.58$ & $6-20$ & 130.9 & 338 & 25 & 15 & 1.43 \\
\hline M5 & 780 & 17.5 & 5.0 & 78.0 & 3.9 & $0.27-1.36$ & $8-21$ & 143.3 & 473 & 63 & 56 & 2.67 \\
\hline GA & 1220 & 12.2 & 3.2 & 64.7 & 4.3 & 0.75 & 16 & 39.0 & 33 & 25 & 34 & - \\
\hline 01 & 1060 & 14.5 & 5.5 & 87.7 & 3.2 & $0.06-0.72$ & $7-22$ & 55.2 & 148 & 42 & 8 & 1.68 \\
\hline 62 & 780 & 23.2 & 4.5 & 119.7 & 7.0 & $0.02-2.58$ & $11-20$ & 75.4 & 301 & 44 & 58 & 1.13 \\
\hline Mal & 1020 & 16.5 & 8.5 & 56.7 & 3.2 & $0.04-1.08$ & $8-18$ & 74.6 & 173 & 44 & 8 & 0.85 \\
\hline$A B 1$ & 1080 & 5.7 & 3.0 & 45.2 & 3.2 & $0.14-0.32$ & $9-15$ & 271.0 & 399 & 40 & 7 & 0.69 \\
\hline$A B 2$ & 760 & 16.5 & 1.0 & 135.8 & 4.1 & $0.21-0.70$ & $12-21$ & 227.5 & 712 & 83 & 87 & 2.05 \\
\hline
\end{tabular}


highest station was sampled in the morning and the lowest station in the afternoon. Sampling stations marked with " $A$ » in fig. 1 were sampled only during August 1986. Samples from Monachil stream were obtained for an hour each month during the period February-December 1987. In addition, handnet collections were taken from the stream banks where the pupal exuviae usually accumulate, especially in low-flow conditions. Drift-net and handnet collections were put together in a single sample.

\section{Results and discussion}

\subsection{General characteristics of lotic chironomid fauna of the Sierra Nevada}

A total of 81483 pupal exuviae and pupae was sampled and sorted, and 143 chironomid species were identified. Orthocladiinae ( 78 species, $54.2 \%$ ) tended to dominate, this situation being characteristic of headwaters (Thienemann 1954). Tanytarsini (22 species, $15.5 \%$ ) and Chironomini (16 species, $11.3 \%$ ) were represented by intermediate frequencies, Tanypodinae (13 species, $9.1 \%$ ) and Dia- mesinae (12 species, $8.6 \%$ ) showed similar diversities. Prodiamesinae were represented by 2 species $(1.4 \%)$.

The altitudinal changes in the relative abundance of the main chironomid taxa from Monachil stream is represented in fig. 2 . Along the reach sampled, Orthocladiinae dominate numerically. Diamesinae, constituting approximately $35 \%$ in the headwaters, fell to less than $2 \%$ at M5. On the other hand, Chironomini, almost absent at $\mathrm{M} 1$ and $\mathrm{M} 2$, increased downstream to $8.5 \%$ at M5, this increase coinciding with sewage input at this site $\left(\right.$ see $\mathrm{BOD}_{5}$, Table 1).

The most abundant genera and species from all the 10 streams studied are listed in Table 2. Eukiefferiella and Tvetenia were the dominant genera both specifically and numerically. Most species of these genera live in fast-flowing and well-oxygenated waters (Lehmann 1972). Orthocladius and Cricotopus were also well represented. Rheocricotopus was represented by 7 species, although it was numerically a scarce genus. Species of this genus are usually

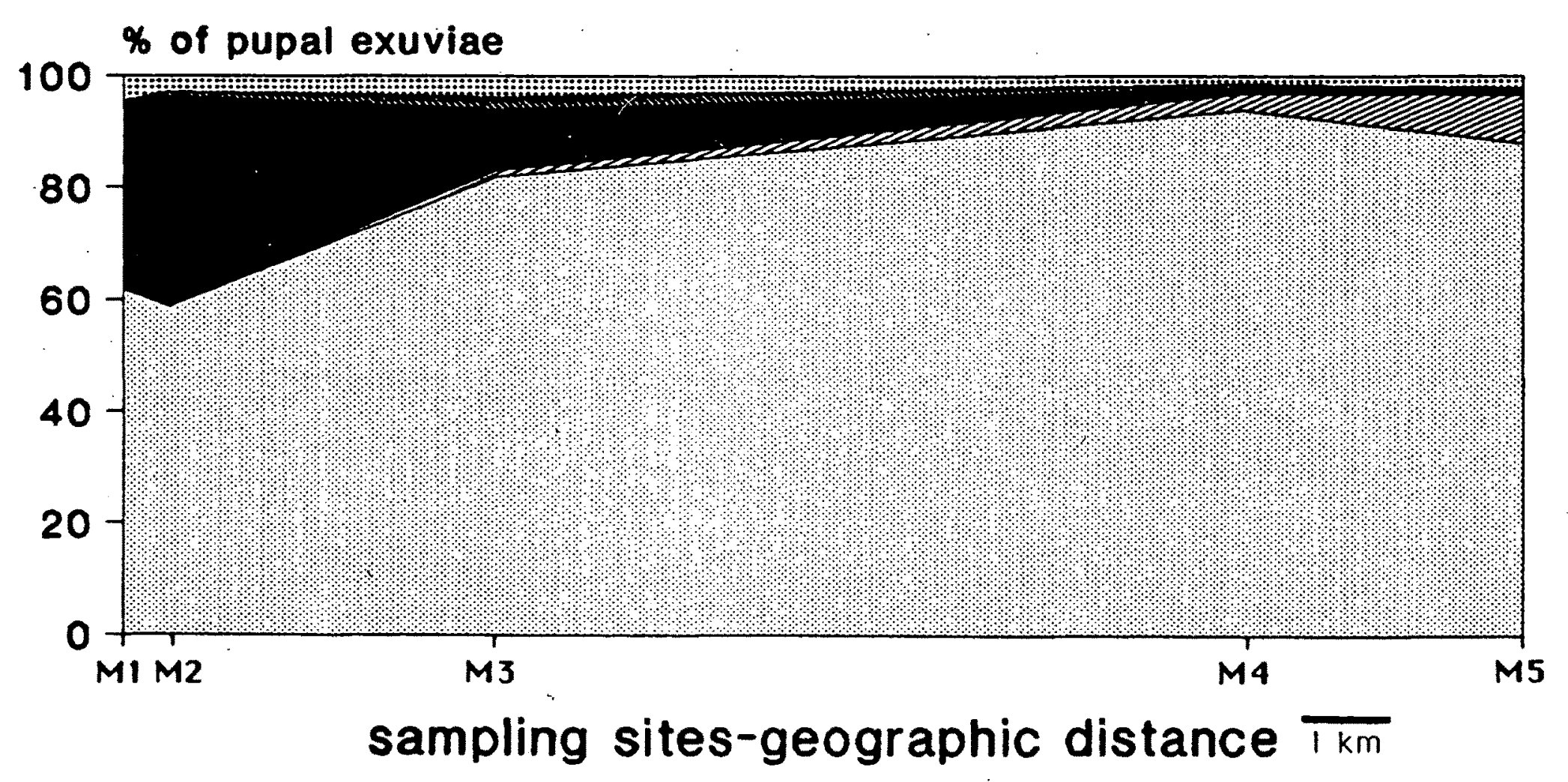

\section{ORTHOCLADIINAE CHIRONOMINI \\ DIAME.+ PRODIAME. TANYPODINAE \\ TANYTARSINI}

Fig 2. Altitudinal changes of the frequency of the chironomid subfamilies or tribes along the Monachil stream.

Fig. 2. Evolution altitudinale de la fréquence des sous-familles ou tribus de Chironomidés. 
Table 2. Number of species for the main chironomid genera and percentages of the main genera and species present in the streams from the Sierra Nevada.

Tableau 2. Nombres d'espèces des principaux genres et pourcentages des principaux genres et espèces de Chironomidés des rivières de la Sierra Nevada.

\begin{tabular}{lcrll}
\hline GENERA & N species & $\%$ & SPECIES & $\%$ \\
\hline $\begin{array}{l}\text { Eukiefferiella } \\
\quad+\end{array}$ & 15 & 30.1 & & \\
$\begin{array}{l}\text { Tvetenia } \\
\text { Cricotopus }\end{array}$ & 11 & 9.4 & E. cyanea & 9.1 \\
Orthocladius & 9 & 14.2 & Cricotopus ssp. & 7.1 \\
Rheocricotopus & 7 & 1.2 & P. rufiventris & 6.9 \\
Diamesa & 6 & 1.6 & E. devonica & 6.5 \\
Polypedilum & 5 & 2.3 & E. claripennis & 6.3 \\
Micropsectra & 4 & 4.2 & P. stylatus & 5.1 \\
\hline
\end{tabular}

recorded from reaches with abundant submerged macrophytes (Lindegaard-Petersen 1972, Cranston et al. 1983, Bass 1986), these being unusual in fastflowing streams.

The most abundant species ( $>5 \%$, Table 2) were 7 Orthocladiinae species or taxa (Cricotopus spp.) which together constituted $50.4 \%$ of the total. Most of these, widely distributed in the Palaearctic region, are rheophilic and prefer the headwaters (Lehmann 1971, Laville \& Lavandier 1977, Verneaux \& Vergon 1974, Ringe 1974, Wilson 1977, Laville 1981).

\subsection{Altitudinal distribution of the species}

In Table 3 we have represented the relative abundance, according to altitude, of the 99 most frequent chironomid species. The lines represent the altitudinal distribution of each species, even if absent at intermediate sampling stations. We used lines instead of dots for graphic clarity. In no case we did join two very distant points of distribution in the altitudinal gradient without another point between them.

Most Tanypodinae species were poorly represented at all sampling stations. Macropelopia nebulosa, considered by Wilson (1980) as a potamal species, was nevertheless recorded from $940 \mathrm{~m}$ to $2100 \mathrm{~m}$, in accord with its eurythermal and eurytopic character proposed by Caspers \& Reiss (1987). The distribution of this species seems mostly determined by the presence of a soft organic substratum (Buisson 1986).
Diamesinae species were arranged by Serra-Tosio (1973) into 3 groups according to their altitudinal distribution and water-temperature margins in the French Alps and the Massif Central. Only Pseudodiamesa nivosa, which occurs in some high-altitude lagoons ( $>2600 \mathrm{~m}$ ) in the Sierra Nevada (Laville \& Vilchez 1986), was recorded from Serra-Tosio's first group (high-altitude and cold-stenotherm species). For the second group, low-altitude species inhabiting less cold waters, we recorded 3 species in the Sierra Nevada : Sympotthastia zavreli, Potthastia montium and Potthastia gaedii. These species occurred at higher altitudes than in the Alps and the Massif Central, although over a medium-low altitudinal range $(740-1700 \mathrm{~m})$ with respect to the rest of Diamesinae in the Sierra Nevada. The remaining species are included in a group of intermediate species which live mainly in the mid-altitude range. In general, the distribution range of the Diamesinae was noticeably higher in the Sierra Nevada than in the French Alps and the Massif Central. This may be due to the latitudinal difference-the lower latitude of the Sierra Nevada may raise the altitude of the thermal threshold for species which require temperatures lower than $15^{\circ} \mathrm{C}$ (Serra-Tosio 1973). Moreover, the presence of Hydrurus foetidus algae might influence the distribution of the Diamesinae, as some species such as Diamesa zernyi prefer to inhabit this algae (Serra-Tosio 1973, Kownacki 1971), which grows only with ample light and low temperatures, between 2 and $12^{\circ} \mathrm{C}$ according to Bursa (1934). In addition, the impoundment of water mainly below $1000 \mathrm{~m}$ might indirectly affect this distribution pattern, by modifying the thermal regime and current speed conditions.

Among Orthocladiinae, 15 species or taxa were distributed all along the altitudinal profile, and 16 other species were distributed from $600 \mathrm{~m} / 700 \mathrm{~m}$ to the highest sampling station at $2100 \mathrm{~m}$. Some taxa are indicated in Table 3 as a group of species because of the difficulty of distinguishing in their pupal stage. However, some species identifications of imagines $O^{\prime}$ were possible. For example, most of the recorded imagines $\mathrm{O}^{\prime}$ of Corynoneura belonged to C. lobata Edwards, at medium-high altitudes $(940-2100 \mathrm{~m})$; two Thienemanniella species were identified as $T$. cf. morosa (Edwards) and $T$. cf. vittata (Edwards). Parorthocladius nudipennis and Paratrichocladius skirwithensis, despite their wide distribution, are more abundant in the upper reaches, 

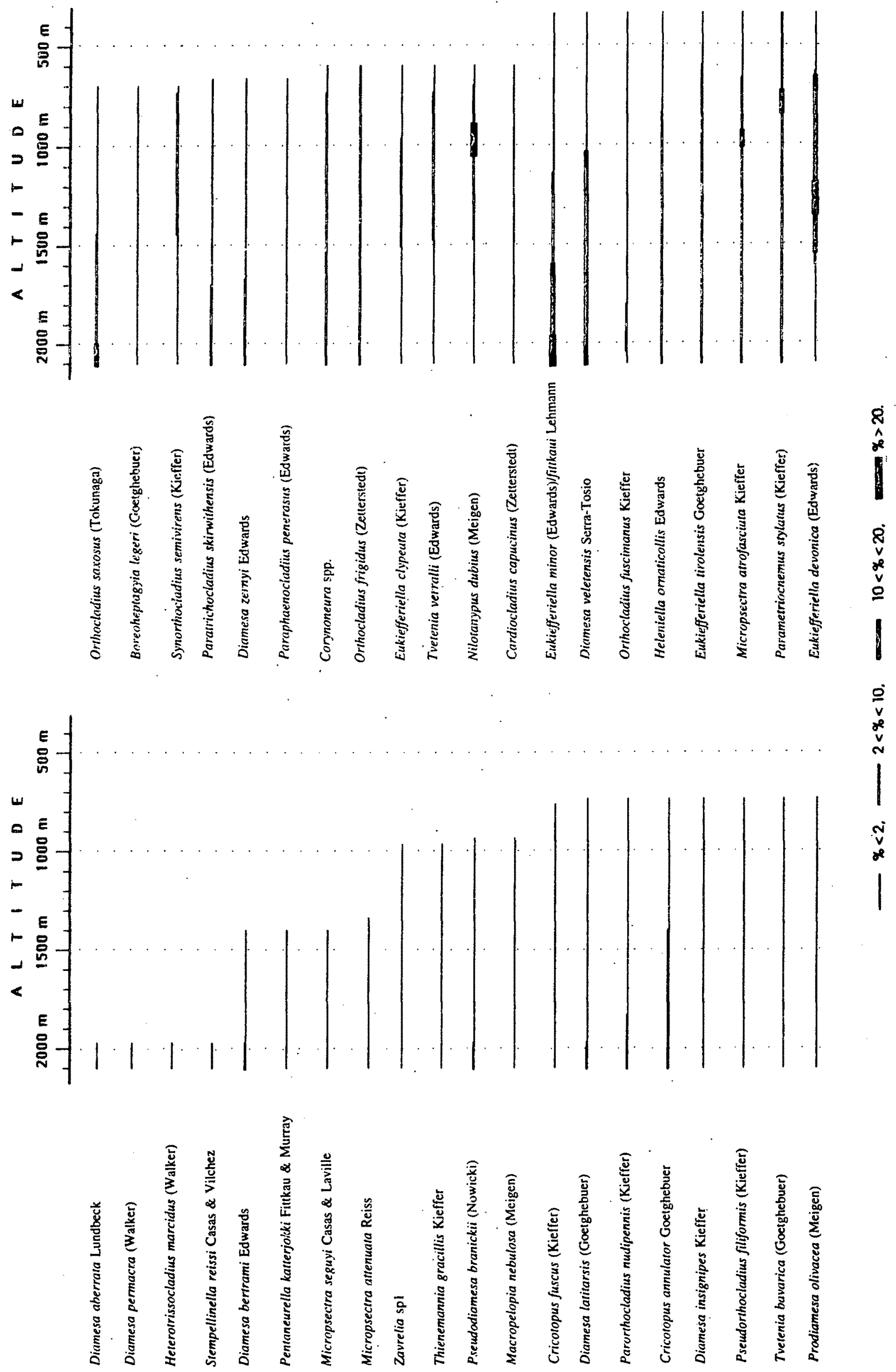


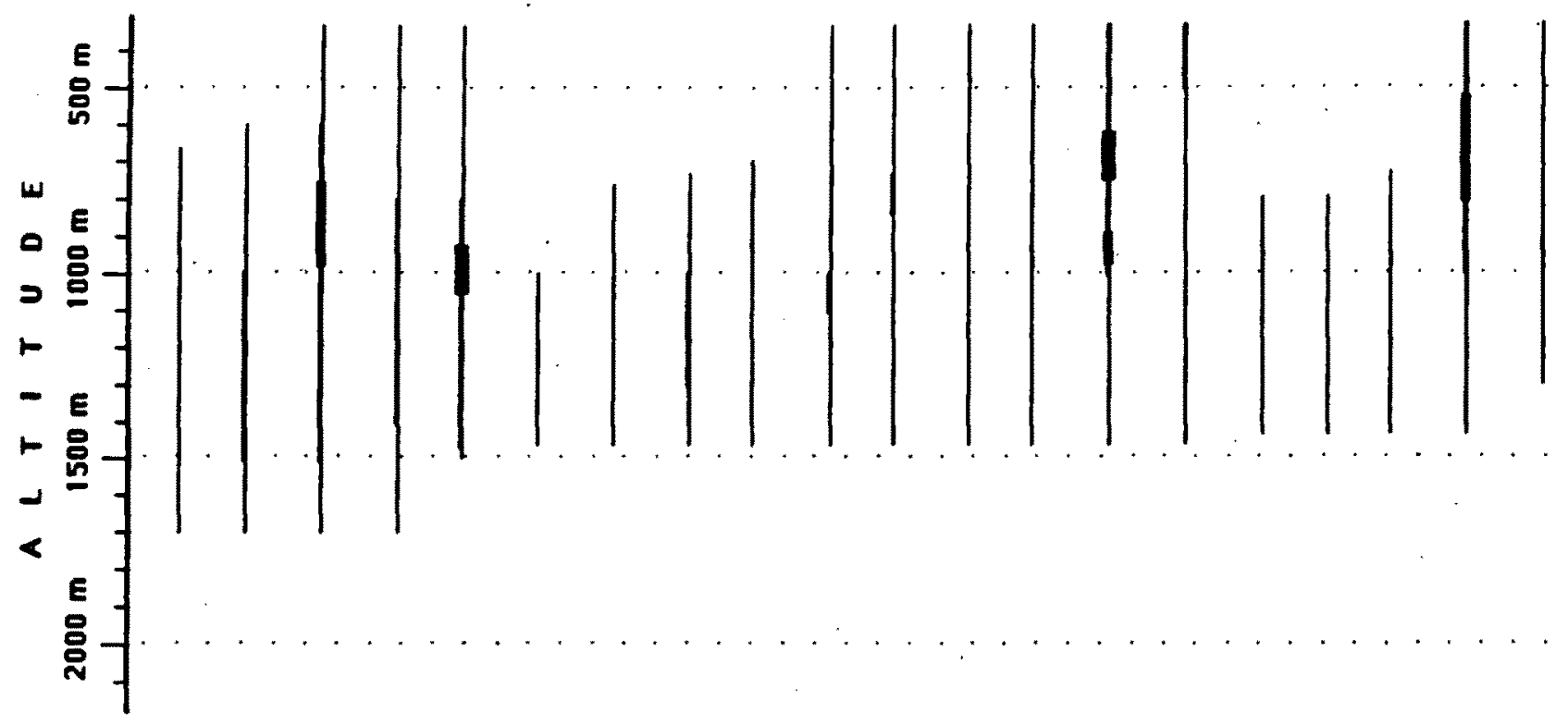

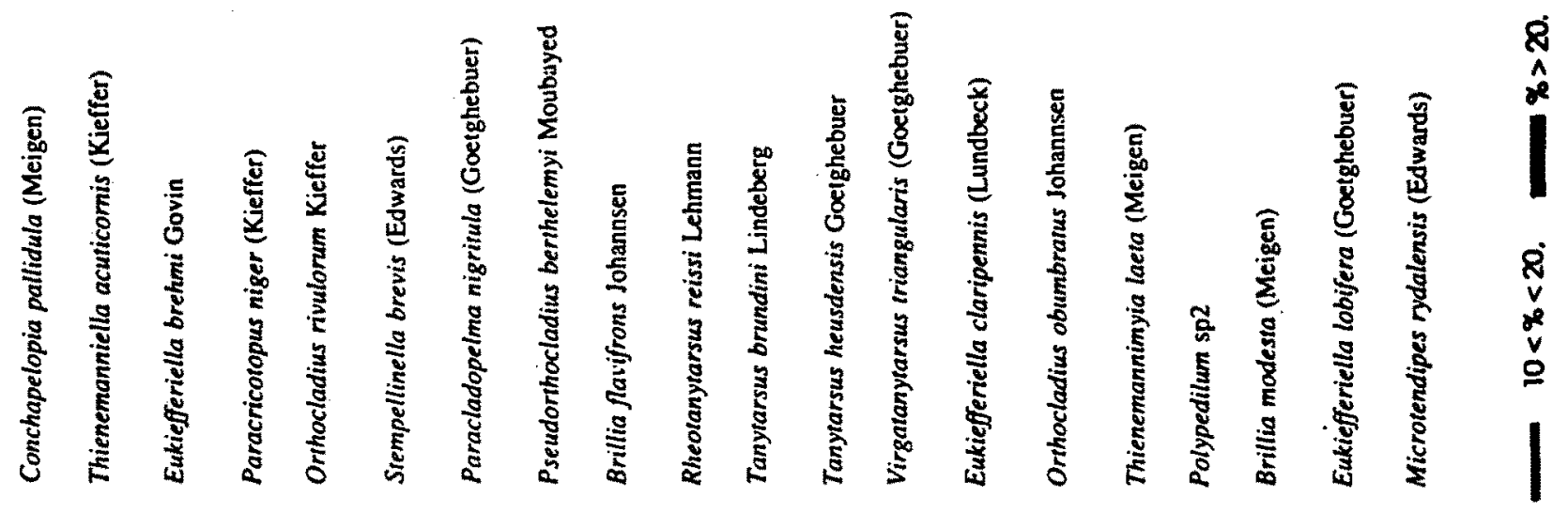
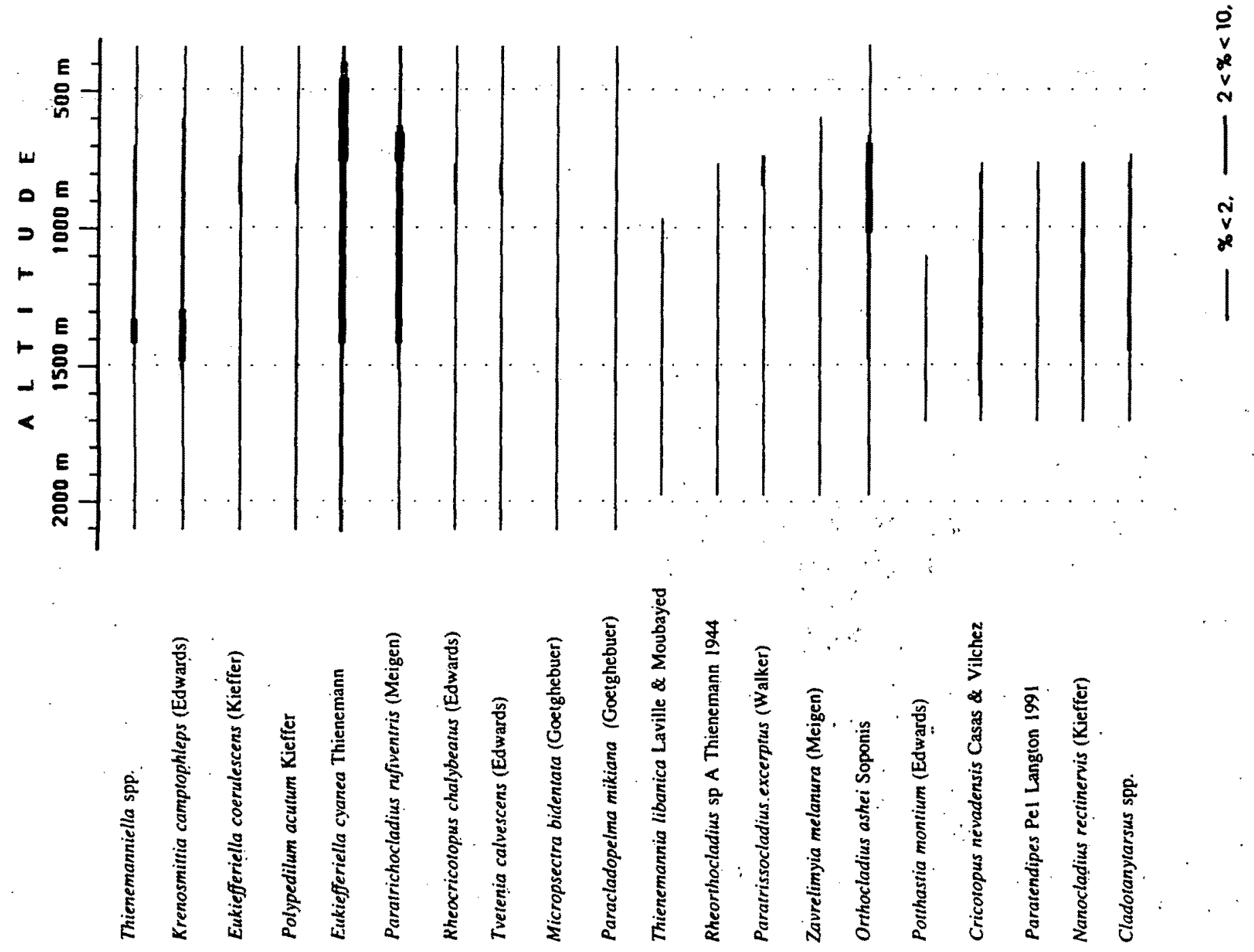


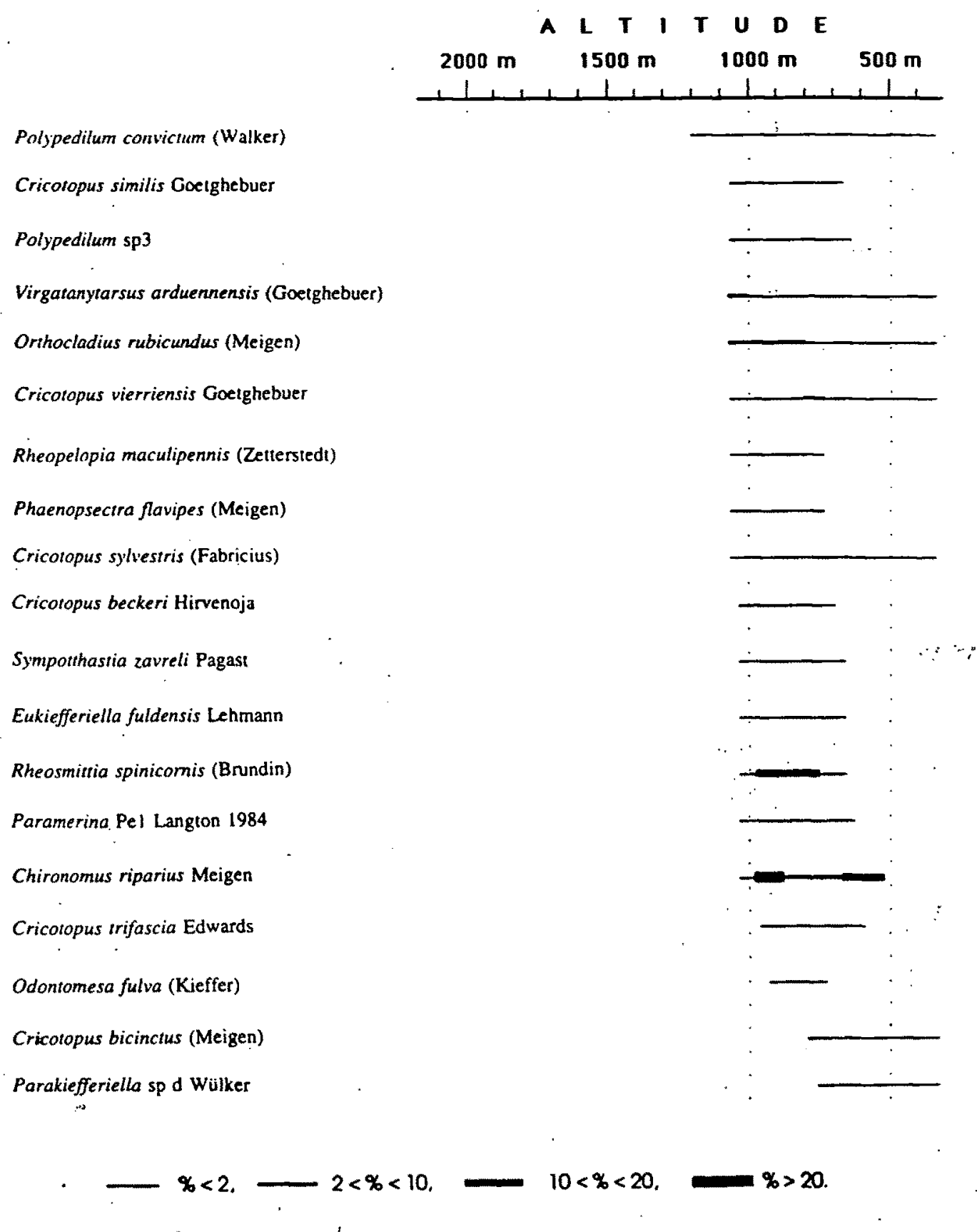

Table 3. Altitudinal distribution of the 99 most common chironomid species in the Sierra Nevada. Relative abundance of the species in respect to the other chironomid species at the stream reach considered.

Tableau 3. Répartition altitudinale des 99 espèces de Chironomidés les plus fréquents dans la Sierra Nevada. Abondance relative de chaque espèce par rapport aux autres Chironomidés dans la station considérée.

and are considered to be cold-stenothermal (Caspers $\&$ Reiss 1987). The first species was recorded mainly from the upper reaches in some southern European rivers (Prat et al. 1984, Rossaro 1991) : the second species is a typical Krenal species, extending to the Rhitral during low-flow periods (Rossaro 1982), and was also signalized as the most abundant species in a low-gradient alpine-tundra stream (Aagaard et al. 1987). These results are consistent with our observation : we recorded $P$. skirwithensis with higher frequency from adjacent sources with low flow at the station M2.
Most of the Cricotopus species were distributed at lower altitudes. $C$. sylvestris and $C$. bicinctus are usually considered as eurythermal and euryecious species (Caspers 1983). The presence of $C$. bicinctus is probably related to the organic input at some low sampling stations (D2, M5). These two species tend to replace other species under conditions of environmental stress (Simpson \& Bode 1980). C, annulator and $C$. nevadensis were distributed at the highest altitudes, the latter species at present knowr only from the Sierra Nevada. 
Most of the Eukiefferiella species were widely distributed all along the altitudinal gradient, although with notable differences in abundance according to the altitude. Eukiefferiella minor/fittkaui is more frequent from 1400 to $2100 \mathrm{~m}$. We recorded a single imago $O^{\prime}$ of $E$. fittkaui at $2100 \mathrm{~m}$, and the remaining imagines belonging to $E$. minor were collected from $750 \mathrm{~m}$ to $2100 \mathrm{~m}$. This distribution agrees with the altitudinal division of both species observed in other rivers or streams (Lehmann 1971, Laville \& Lavandier 1977). E. cyanea, E. clypeata, $E$. devonica and $E$. claripennis are recorded at widely different altitudes in some European rivers (Lehmann 1971, Ringe 1974, Laville \& Lavandier 1977, Laville 1981). The same is true of four Orthocladius species : O. fuscimanus, $O$. ashei, $O$. frigi$d u s$ and $O$. saxosus.

Only two species of Chironomini, Paracladopelma mikiana and Polypedilum acutum, were recorded along the entire profile; nevertheless in the headwaters and upper reaches only one specimen was recorded from the summer sampling. The autoecology of these species is almost unknown. The remaining Chironomini species are distributed mainly in the lower parts of the streams where they often occur in low abundance. Chironomus riparius is more abundant at low sites with sewage input, as is usually recorded (Mc Gill et al. 1979, Hawkes 1978).

Among Tanytarsini, Micropsectra atrofasciata and Micropsectra bidentata had the widest distribution ; both are widely distributed in European rivers. Stempellinella reissi, Micropsectra seguyi and Zavrelia sp1, at present are recorded only from the Sierra Nevada, and although rare, these species seem to prefer the headwaters and upper reaches. The taxa noted in Table 3 as Cladotanytarsus spp., represent at least two species identified using imago $O^{\prime \prime}$ as $C$. atridorsum Kieffer and C. vanderwulpi (Edwards).

\subsection{Comparison with the chironomid zonation of the Pyrenean streams}

The comparison of the atitudinal zonation of the chironomid communities of the Sierra Nevada with those of other European mountain ranges, seems useful only in the case of the Pyrenees (Laville \& Vinçon 1991). Other studies on altitudinal distribution are limited in several aspects, as mentioned above, and present altitudinal gradients hardly comparable with that considered in the present work.

In the Pyrenees, the altitudinal zonation was based mainly on the chironomid communities of two natural lotic basins, little altered by human activity. This study covered an altitudinal range of $2000 \mathrm{~m}$ (400-2400 m), similar to that considered in the Sierra Nevada. Table 4 lists the characteristic or most frequent species in the altitudinal reaches differentiated in the Pyrenees (for detailed information concerning zonation see Laville \& Vinçon (1991). For comparing we have included in Table 4 the most common chironomid species collected in the Sierra Nevada at these reaches (recorded in Table 3). The headwaters are considered by Laville \& Vinçon (1991) to be upstream of $2100 \mathrm{~m}$; however, this is the highest sampling altitude in the Sierra Nevada. Nevertheless, species such as Diamesa aberrata, $D$. permacra, Heterotrissocladius marcidus and Stempellinella reissi are probably more frequent, or at least characteristic, up to $2100 \mathrm{~m}$.

From Table 4 we can draw four generalities :

- The relative low number of common species living in the same reach ;

- The relative high number of species with a different altitudinal distribution pattern, mainly in the middle and foothill reaches ;

- The absence from the Sierra Nevada of a great number of cold-stenothermal Pyrenean species, frequent in the headwaters and upper reaches. At the present time, four characteristic or common elements in the Sierra Nevada, are not recorded in the Pyrenees.

- The relative high number of species with altitudinal distribution patterns which shift toward the upper reaches in the Sierra Nevada with respect to the Pyrenees.

The last two aspects are possibly related to the different latitudinal situations of the two mountain massifs. Additional differences in historical, geographical and physiographical characteristics of the basins (climate, flow regime, gradient, pattern of branching) may also contribute to the differences in altitudinal distribution patterns of species. Furthermore, we should bear in mind that the study carried out in the Pyrenees took place in two basins scarcely altered by human activity, a point well contrasting with our study area. 
Table 4. Characteristic or common chironomid species at different altitudinal reaches in the Pyrenees and in the Sierra Nevada. Tableau 4. Espèces caractéristiques ou communes dans les différentes sections altitudinales des Pyrénées et de la Sierra Nevada.

PTRENEXS

Laville \& Vinçon (1991)

\begin{tabular}{|c|c|c|}
\hline GEADWATER & \multicolumn{2}{|c|}{ Diamesa aberrata } \\
\hline \multirow[t]{2}{*}{$>2000 \mathrm{~m}$} & Pseudadiamesa nivasa & $\begin{array}{l}\text { Diamesa permacro } \\
\text { Hetero. marcidus }\end{array}$ \\
\hline & $\begin{array}{l}\text { Diamesa steinboecki } \\
\text { Diamesa laricauda } \\
\text { Diamesa whelkeri } \\
\text { Parakiefferiello porna }\end{array}$ & Stempellinella reissi \\
\hline \multirow{4}{*}{$\begin{array}{l}\text { UPPER } \\
\text { REACHES } \\
1600-2000 \mathrm{~m}\end{array}$} & \multicolumn{2}{|c|}{ Dianesa berrrami. Pseudadianesa branictii, Euk firkausi } \\
\hline & $\begin{array}{l}\text { Eukiefferiella sirolensis } \\
\text { Micropsectra bidentato }\end{array}$ & Cricotopus annulator \\
\hline & $\begin{array}{l}\text { Diamesa incallida. } \\
\text { Diamesa tonsa } \\
\text { Diamesa lavillei } \\
\text { Diamesa thomasi } \\
\text { Krenosmitria boreoalpina }\end{array}$ & $\begin{array}{l}\text { Diamesa Latitarsis. } \\
\text { Paror. nudipennis } \\
\text { Orthocladius saxosus } \\
\text { Parat. skinwithensis } \\
\text { Diamesa zemyi }\end{array}$ \\
\hline & Krenopsectra fallax & Diamesa veletensis \\
\hline
\end{tabular}

MIDDLE

REACHES

$1000-1600 \mathrm{~m}$

\begin{tabular}{|ll|}
\hline \multicolumn{1}{|c|}{ Nilo. dubius, Hel. omaticollis, Kren. camplophleps, Orth. rivulorwn } \\
\hline Eukiefferiella fuldensis & Sym. semivirens \\
Corynoneura lobata & Tvetenia verralli \\
Tvetenia bavarica & Eukiefferiella devonica \\
Paracladopelma mikiana & Pseud. berthelemyi \\
Polypedilum albicome & Rheotanytarsus reissi \\
Micropsectra lindrothi & \\
\hline
\end{tabular}

\begin{tabular}{|l|l|}
\hline $\begin{array}{l}\text { Diamesa latitarsis } \\
\text { Diameso zemyi } \\
\text { Orhocladius saxosus } \\
\text { Parat. skimithensis } \\
\text { Paror. nudipennis }\end{array}$ \\
\hline
\end{tabular}

Rheocricotopus nigricauda

Cricotopus nevadensis

\begin{abstract}
FOOTHLL
\end{abstract}
REACHES

$<1000 \mathrm{~m}$

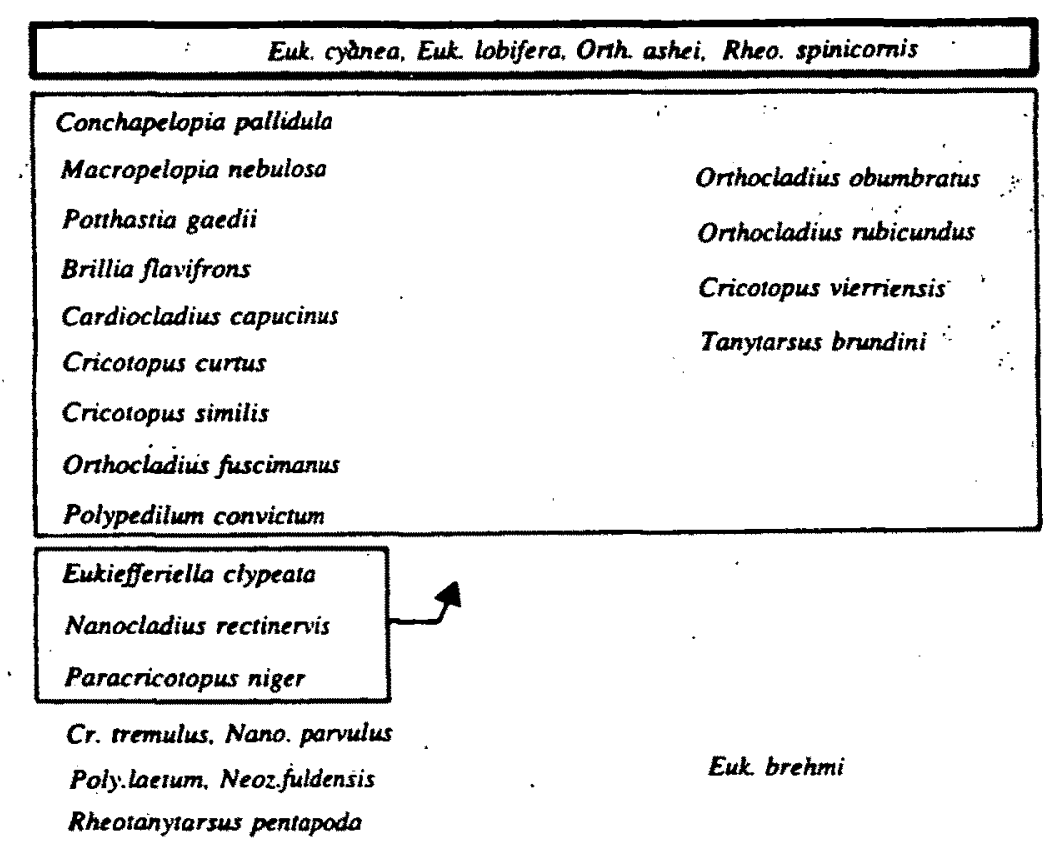

Species out of the boxes, not in common; $\square$ species $h$ common: $\square$ species with divergence or rare:

species in common in the next upper or lower reach respectively 
The most useful comparison of altitudinal profiles between these two distantly separate mountain areas, would be on the basis of patterns of community diversity. In the Pyrenees, the species richness increases from the headwaters toward the foothill reaches, where the maximum average richness occurs. According to Laville \& Vinçon (1991), the decrease in slope and the increase in flow favour the colonization of a community richer in potamophilic Tanypodinae and Chironominae species. In the Sierra Nevada, an increase in the species richness took place down-stream as well, from the headwaters ( 58 species), through the upper reaches ( 72 species), to the maximum in the middle reaches (121 species). But a somewhat lower species richness appeared in the foothill reaches (113 species). Thienemann (1954) observed the most diversified chironomid communities in the foothill reaches, where the greatest biotope diversity occurs. Ward (1986) found a similar pattern in the species richness of macroinvertebrates of a Rocky Mountain river : the higher species richness at the foothill sites was related to a faunistic discontinuity produced by the tran- sition from the Rhithral to the Potamal conditions. Such foothill reaches coincide mostly with 3rd and/or 4th order streams, that in the northern temperate regions have the greatest chironomid richness, according to Coffman (1989) ; many factors operate in this increase, mainly related to the greater ecological heterogeneity of the streams with intermediate width and altitude.

The general tendency throughout the Sierra Nevada, can be observed as well in the particular case of the Monachil stream (Fig. 3), where the collecting effort was greatest, and therefore the probability of bias lesser. This decreasing diversity seems to be caused by two kinds of factors, natural and human, which coincide mainly in the foothill reaches of the Sierra Nevada streams. The natural factors refer to the geologic composition and structure of this mountain massif. It has a core of cristalline materials and a border of limestone which is mainly exposed in the foothil sites. The channels are relatively wide in the cristalline region, above the foothill, but begin to become narrow, and in

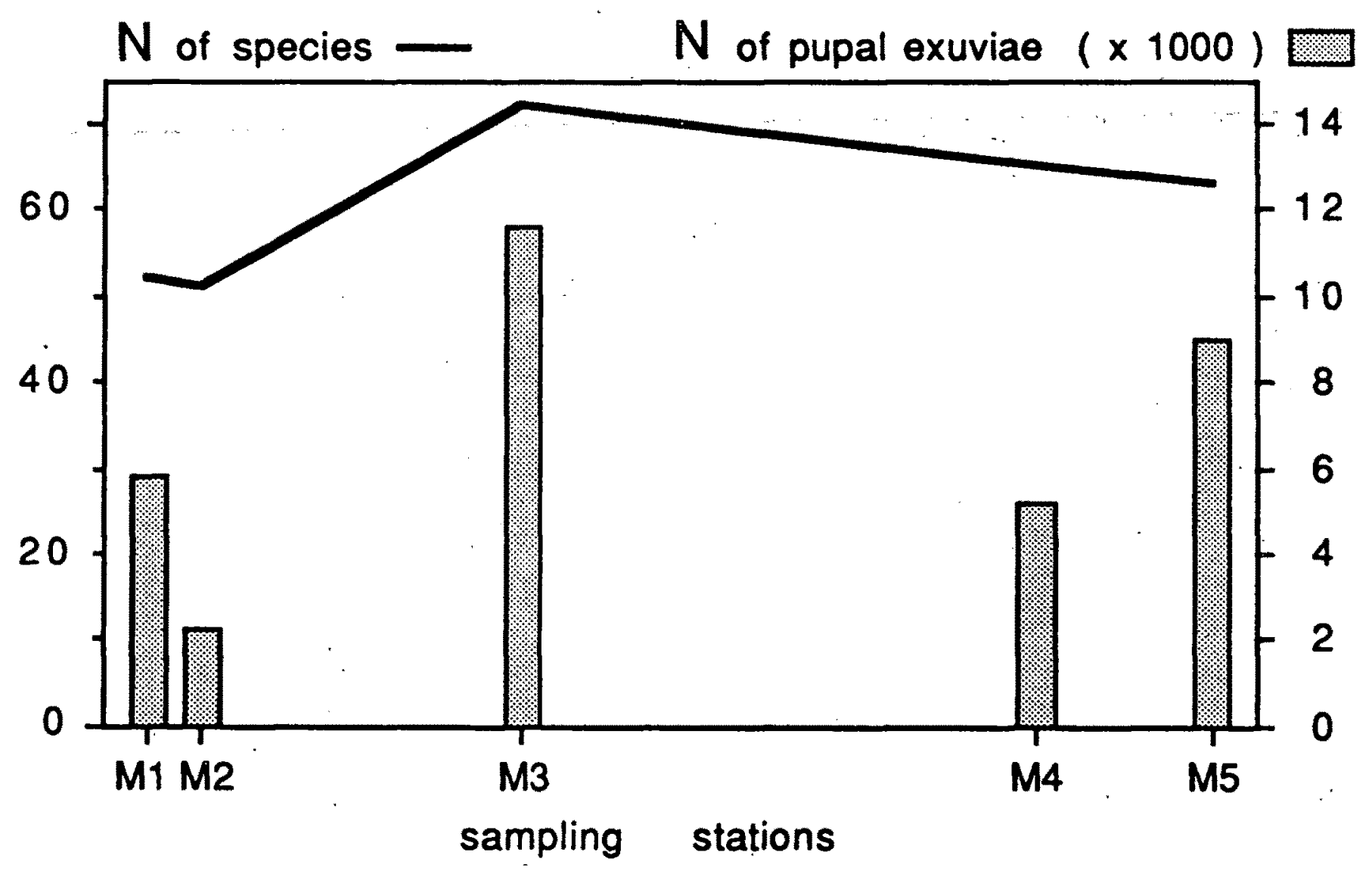

Fig. 3. Altitudinal changes in chironomid species richness and total number of pupal exuviae collected at each sampling station in the Monachil stream.

Fig. 3. Evolution altitudinale de la richesse spécifique et du nombre total d'exuvies nymphales récoltées dans chaque station de la rivière Monachil. 
many cases strongly shaded because of the very close riparian canopy: Both narrowness and shade may be responsible, at least in part, for the decrease in chironomid species richness (Hawkins et al. 1982, Lenat 1983, Coffman 1989). On the other hand, two human activities are particularly intense below $1000 \mathrm{~m}$ : sewage input and water impoundment. Sewage input, condiserable in certain sampling stations (see $\mathrm{BOD}_{5}$, Table 1), limits habitat heterogeneity excluding a large number of species in favour of a few, such as Eukiefferiella claripennis, Chironomus riparius, Micropsectra atrofasciata and Paratrichocladius rufiventris (Table 3). Furthermore, the impoundment of water may cause important changes in lotic communities : flow reduction, according to Ward (1976), brings about certain physical changes that decrease the number of species. Water diversion for agriculture and small power stations results in long periods of reduced and intermittent flow in certain stations of the lower reaches (Table 1).

\section{Conclusions}

The altitudinal distribution of some chironomid species in the Sierra Nevada streams, coincides with that of other European water courses. Nevertheless, in many cases, as in the Diamesinae species, the range of distribution in the Sierra Nevada was noticeably higher in altitude than in the French Alps and the Massif Central. The same tendency can be found in comparison with the Pyrenean zonation. In addition, there was an absence in the Sierra Nevada of a great number of cold-stenothermal Pyrenean species. Both tendencies may be connected with the different latitudinal situation of these two mountain massifs. Furthermore, there was a relatively high number of species with a different altitudinal distribution pattern, which can be attributable to many historical, geographical and physiographical differences between the two massifs.

The theoretically expected highest species richness in the foothill sites was not obtained. Periods of reduced or intermittent flow, the sewage input and the narrowness of the channels in the foothill sites appear to decrease the species richness of the chironomid communities. It remains to be seen to what extent human activity and natural factors, separately, influence chironomid species richness.

\section{Acknowledgements}

We are grateful to Dr. W.P. Coffman for helpful comments, correcting an early English version of the manuscript and the facilities provided in his laboratory. Were are also indebted to $\mathrm{Dr}$. H. Laville, Dr. F. Reiss and Dr. B. Serra-Tosio, for their taxonomic help.

\section{References}

Aagaard K., Olsen A. \& Solem J.O. 1987. - Chironomids of Blesbekken, an alpine tundra stream at Dovrefjell national park, Norway. Ent. scand. Suppl., 29 : 349-360.

Bass D. 1986. - Larval Chironomidae (Diptera) of the Big Thicket streams. Hydrobiologia, $135: 271-285$.

Brouquet-Laglaire Y. 1985. - Etude des Chironomides (Diptera) de quelques rivières polluées du bassin de la Garonne : Touyre, Agout, Dadou, Thoré, Bas Lot. Thèse $3^{e}$ cycle, Univ. Paul Sabatier, Toulouse, $237 \mathrm{p}$.

Buisson J. 1986. - Hydrobiologie du massif du Vercors (Préalpes calcaires) et d'une rivière type : le Furon. Ecologie des Diptères Chironomidae du Furon et de quelques cours d'eau pollués. Thèse de $3^{\mathrm{e}}$ cycle, Univ. de Grenoble.

Bursa M.A. 1934. - Hydrurus foetidus Kirch. w Polskich Tatrach. 1. Hydrurus foetidus Kirch in der Polnischen Tatra. Oecologie, Morphologie. 1. Memoire aus dan Institut fur pharmazautischen Botanik an der Jagellonischen Universitat, Krakow.

Casas J.J. \& Vilchez-Quero A. 1989. - A faunistic study of the lotic chironomids (Diptera) of the Sierra Nevada (S.E. of Spain) : Changes in the structure and composition of the populations between spring and summer. Acta Biol. Debr. Oecol. Hung., $3: 83-93$.

Caspers N. 1983. - Chironomiden Emergenz zweier Lunzer Bäche, 1972. Arch. Hydrobiol. Suppl., 65 : 484-549.

Caspers N. \& Reiss F. 1987. - Chironomidae des Lunzer Seengebietes in Niederosterreich (Insecta, Diptera, Nematocera). Spixiana, $10: 13-35$.

Coffman W.P. 1973. - Energy flow in a woodland stream ecosystem. II. The taxonomic composition and phenology of the Chironomidae as determined by collection of pupal exuviae. Arch. Hydrobiol., 71 : 281-322.

Coffman W.P. 1989. - Factors that determine the species richness of lotic communities of Chironomidae. Acta Biol. Debr. Oecol. Hung., 3 : 95-100.

Cranston P.S., Oliver D.R. \& Saether O.A. 1983. - The larvae of Orthocladiinae (Diptera : Chironomidae) of the Holarctic region.-keys and diagnosis. Ent. scand. Suppl., 19 : 149-291.

Giller P.S. 1984. - Community Structure and the Niche. London, Chapman and Hall. 176 p.

Hawkes H.A. 1978. - Invertebrates as indicators of rivers water quality, pp. 21-245. In : A. James and L. Evinson (eds.). Biological indicators of water quality. John Wiley and Sons, Inc. New York, N4. 597 p:

Hawkins C.P., Murphy M.L. \& Anderson N.H. 1982. - Effects of canopy, substrata composition and gradient on the structure of macroinvertebrate communities in Cascade Range streams of Oregon. Ecology, $63: 1840-1856$.

Hayes B.P. \& Murray D.A. 1988. - Diel variation in chironomid emergence and implications for the use of pupal exuviae in river clasification. Verh. Int. Ver. Limnol., 23 : 1261-1266. 
Kownacki A. 1971. - Taxocens of Chironomidae in streams Polish High Tatra Mts. Acta Hydrobiol. Krakow, 13 : 439-464.

Laville H. 1979. - Etude de la dérive de exuvies nymphales des Chironomides au niveau de confluent Lot-Truyère. Annls. Limnol., 15 (2) : 155-180.

Laville H. 1981. - Récolte d'exuvies de Chironomides dans le Haut-Lot, de la source $(1295 \mathrm{~m})$ au confluent de la Truyère (223 m). Annls. Limnol., 17 (3) : 255-289.

Laville H. \& Lavandier P. 1977. - Les Chironomides (Diptera) d'un torrent pyrénéen de haute montagne : L'Estaragne. Annls. Limnol., 13 (1) : 57-81.

Laville H. \& Vilchez-Quero A. 1986. - Les Chironomides (Diptera) de quelques « Lagunas » de haute altitude de la Sierra Nevada (Granada, Espagne). Annls. Limnol., 22 (1) : 53-63.

Laville H. \& Vinçon G.1991. - A typological study of Pyrenean streams : Comparative analysis of the Chironomidae (Diptera) communities in the Ossau and Aure Valleys. Verh. Int. Ver. Limnol., 24 : 1775-1784.

Lehmann J. 1971. - Die Chironomiden der Fulda (systematische, okologische und faunistiche Untersuchungen). Arch. Hydrobiol. Suppl., 37 : 466-555.

Lehmann J. 1972. - Revision europaischen Arten von Eukiefferiella Thienemann. Beitrag. Ent. Bd., 22 (7-8) : 348-405.

Lenat D.R. 1983. - Chironomid taxa richness : natural variation and use in pollution assessment. Freshwat. Invertbr. biol., 2 (4) : 192-198.

Lindegaard-Petersen C. 1972. - An ecological investigation of the Chironomidae (Diptera) from a Danish lowland stream (Linding A). Arch. Hydrobiol., 69 (4) : 465-507.

Mc Gill J.D., Wilson R.S. \& Brake A.M. 1979. - The use of chironomid pupal exuviae in the surveillance of sewage pollution within a drainage system. Water Research, $13: 889-894$.

Prat N., Puig M.A., Gonzalez G. \& Millet X. 1984. Chironomid longitudinal distribution and macroinvertebrate diversity along the Llobregat river (NE Spain). Mem. Am. Entomol. Soc., 34 : 267-278.
Ringe F. 1974. - Chironomiden-Emergenz 1970 in Breitenbach und Rohrwiesenbach. Schlitzer Produktions-biologische Studien, 10 : Arch. Hydrobiol. Suppl., 45 : 212-304.

Rossaro B. 1982. - Guide per il riconoscimento delle especie animali delle aque interne italiana, $n^{\circ} 16$. Chironomidi, 2 (Diptera, Chironomidae : Orthocladiinae). Consiglio Nacionale delle Ricerche, aq. 171 p.

Rossaro B. 1991. - Chironomids of stony bottom streams : a detrended correspondence analysis. Arch. Hydrobiol., 122 (1) : 79-93.

Serra-Tosio B. 1973. - Ecologie et biogeographie des Diamesini d'Europe (Diptera, Chironomidae). Trav. Lab. Hydrobiol. Grenoble, 63 : 5-175.

Simpson K.W. \& Bode R.W. 1980. - Common larvae of Chironomidae (Diptera) from New York State streams and rivers, with particular reference to the fauna of artificial substrates. Bull. N.Y. State Mus., $439: 1-105$.

Thienemann A. 1954. - Chironomus. Leben, Verbreitung und wirtschafliche Bedeutung der Chironomiden. Binnengewässer, $20 ; 834 \mathrm{p}$.

Verneaux J. \& Vergon J.P. 1974. - Faune dulçacuicole de France-Comté. Sixième partie : Les Diptères Chironomides. Ann. Scient. Univ. Besançon Zool., 11 : 179-198.

Ward J.V. 1976. - Effects of flow patterns below large dams an stream benthos: A review ; 235-253. In : J.F. Orsborn \& C.H. Alman (eds.). Instream Flow Needs Symposium. Vol. II Amer. Fish. Soc., Bethesda, Md.

Ward J.V..1986. - Altitudinal zonation in a Rocky Mountain stream. Arch. Hydrobiol. Suppl., 74 : 133-199.

Wilson R.S. 1977. - Chironomid pupal exuviae in the River Chew. Freshwater Biol., 7 : 9-17.

Wilson R.S. 1980. - Classifying rivers using Chironomid pupal exuviae, 209-216. In : Chironomidae, Ecology, Genetic and Physiology. IX International Symposium on Chironomidae. Murray D.A. (ed.). Pergamon Press. Dublin.

Wilson R.S. \& Bright P.L. 1973. - The use of Chironomid pupal exuviae for characterizing streams. Freshwater Biol. $3: 283-302$. 